ORIGINAL SCIENTIFIC PAPER

RECEIVED: JANUARY 2016

REVISED: APRIL 2016

ACCEPTED: MAY 2016

DOI: 10.1515/ngoe-2016-0008

UDK: 659.2:004

JEL: 033

Citation: Perko, I., \& Ototsky, P. (2016).

Big Data for Business Ecosystem

Players. Naše gospodarstvo/Our

Economy, 62(2), 12-24. DOI: 10.1515/ ngoe-2016-0008

\section{Big Data for Business Ecosystem Players}

\section{Igor Perko}

University of Maribor, Faculty of Economics and Business, Slovenia igor.perko@um.si

\section{Peter Ototsky}

Russian Academy of Sciences, Keldysh Institute of Applied Mathematics, Russia

peter@ototsky.com

\begin{abstract}
In the provided research, some of the Big Data most prospective usage domains connect with distinguished player groups found in the business ecosystem. Literature analysis is used to identify the state of the art of Big Data related research in the major domains of its use-namely, individual marketing, health treatment, work opportunities, financial services, and security enforcement. System theory was used to identify business ecosystem major player types disrupted by Big Data: individuals, small and mid-sized enterprises, large organizations, information providers, and regulators. Relationships between the domains and players were explained through new Big Data opportunities and threats and by players' responsive strategies. System dynamics was used to visualize relationships in the provided model.
\end{abstract}

Keywords: Business ecosystems; Big Data; information providers; system dynamics

\section{Introduction}

Big Data (BD)-related technologies-namely, data extraction and blending, predictive analytics, and user experience-provide a disruptive force by redefining the communication patterns and the insight levels on all players in business ecosystems and surrounding social and natural systems. BD positively influences the reactivity and provides a higher level of transparency (McAfee \& Brynjolfsson, 2012).

Players in business ecosystems (BE) face new opportunities and challenges to survive and thrive (Evans, 2014). The BD effect on BE is twofold: On one hand it provides new means to execute internal and external processes faster and cheaper; on the other hand, the higher ecosystem security level enables the option to lower the barriers that protected companies in the previously hostile environment. Consequently, the roles of existing players shift and new players emerge on the field, such as system integrators, providing BD-supported networking services.

System thinking provides the theoretical basis for understanding complex systems on multiple levels (Lane, 2000). It also provides a rich toolset, such as system 
dynamics, to help us understand the system members, their relationships, and the triggers that direct their behavior. $\mathrm{BD}$ technologies influence BE players through multiple domains, identifying opportunities and threats for the players. Players respond by using diverse strategies. In this paper, we provide an oversight of the influences BD will have on the BE players, using system thinking as a tool. We focus on a combination of the limited number of $\mathrm{BD}$ domains-namely, individual marketing, health treatment, work opportunities, financial services, and security enforcement-with a selected group of players: individuals, small and mid-sized enterprises (SMEs), large organizations, information providers, and regulators.

The paper is organized as follows. First, relevant backgrounds and the state of the art of $\mathrm{BD}, \mathrm{BE}$, and system thinking are elaborated. Next, BE players' objectives are elaborated and, according to the selected BD domains, opportunities and threats to players' responsive strategies are explained. Then the system dynamics overview is provided, visualizing the relationships between $\mathrm{BD}$ domains and $\mathrm{BE}$ players. The paper concludes with a discussion and future directions. The paper offers insights for BD architects regarding which services to design, business managers regarding what to expect from $\mathrm{BD}$ technologies, and researchers who plan to design BE to help them formulate a requisitely holistic set of requirements.

\section{Background}

\subsection{Big Data}

BD technologies of information processing (such as MapReduce) first appeared for searching and parsing Internet (Bryant, Katz, \& Lazowska, 2008; Lämmel, 2008). The BD boom correlates with exponential growth of stored and sent information and will eventually lead to a metasystem transition of information technologies and shift in progress direction (Press, 2013). The digitalization of BE is part of that transition (Bryant et al., 2008; Cukier, 2014; Evans, 2014; McAfee \& Brynjolfsson, 2012).

Historically, enterprise information systems (EIS), commonly known by its key subsystem enterprise resource planning (ERP) solutions, operate with internal data corresponding to a structure of the business. In fact, IT companies implement not only IT systems (ERP, etc.), but also enforce typical business models and structures. The standardization of business models logically follows the technical aspect: Data models and business logics are programmed in a database structure at a low level (Davenport, 1998; Wood, 2010). Subsequent the organization processes are limited by the EIS variety and can hardly cope with the internal complexity or the complexity of the BE (Waelchli, 1989).

One of the key BD technologies is MapReduce scalable distributed computing (Lämmel, 2008). The idea is that very simple processing is carried out in two stages: (1) map-one large computational task is divided to many similar small tasks and small tasks are then processed on distributed nodes; and (2) reduce-all results are combined into the one result. If the node is a human, not a computer, then the same MapReduce logic may be used for task distribution to performers (crowd sourcing). In this way, the "act” part can be also digitalized using the same BD methods as in the "sense" part.

Predictive analytics exploits the BD potentials not only to provide the whole picture, but also to predict future events (Waller \& Fawcett, 2013). Combining BD and predictive analytics is an extremely powerful combination. It enables organizations to use collective memory in planning their actions, thereby provide management the sharable vision of the future and the capability to anticipate the unexpected.

\subsection{Business ecosystems}

Moore (1993, p. 2) defined business ecosystems as an economic community supported by a foundation of interacting organizations and individuals - the organisms of the business world. The economic community produces goods and services of value to customers, who are themselves members of the ecosystem. The member organisms also include suppliers, lead producers, competitors, and other stakeholders. In a business ecosystem, companies coevolve capabilities around a new innovation: they work cooperatively and competitively to support new products, satisfy customer needs, and eventually incorporate the next round of innovations. Over time, they tend to align themselves with the directions set by one or more central companies. Those companies holding leadership roles may change over time, but the function of ecosystem leader is valued by the community because it enables members to move toward shared visions to align their investments, and to find mutually supportive roles.

$\mathrm{BE}$ are not formalized; therefore, they provide a challenge for researchers to identify their structure, relationships, processes, and-above all-the reason for their existence. Gao, Zhang, Tian, Guan, and Li (2013) combined the evolutionary aspect of complex network theories to explain the e-BE development. Hellstrom, Tsvetkova, Gustafsson, and Wikstrom (2015) identified the cooperation mechanisms and their effect on closer collaboration, sustainability, and increased overall value creation. They pinpointed the 
importance of identifying the factors driving the business models of the collaborating companies to facilitate changes. BE sizes range from closed supply chains, through local habitats, such as cities or national economies (Mavric, Tominc, \& Bobek, 2014; McAfee \& Brynjolfsson, 2012), to global markets (Korez-Vide, 2004; Umpleby \& Lim, 2007).

BE consist of multiple players' roles. Basic entities in BE are individuals and organizations in the form of companies, information service providers, and regulators. Each player follows the goal of surviving and maximizing the bounty gained from the system. The strategies they use depend on the ecosystem resources, rules, and knowledge about how to exploit them.

Individuals follow their objectives or act as agents for the accomplishment of the organization's goals. Regardless of the role they play, the system is organized to utilize capacities and fulfill desires of every individual. The individual's personal engagement, and consequently the organizations' success, depends on the organizations' preparedness to represent their beliefs and support their needs and interests (Drucker, 2002; Waelchli, 1989). The behavior analysis and predictions found key individuals related to research issues (Ajzen, 1991; Nelson, 1970; Zhang, Chen, Mao, Hu, \& Leung, 2014).

Companies ranging from micro enterprises to SMEs and large multinational organizations (Barney, 1991) use their knowledge and means to efficiently produce products and services from the available resources. They actively communicate with external players and employees (Frohlich \& Westbrook, 2001; Tomlin, 2006). Dunkl, Jiménez, Zizek, Milfelner, and Kallus (2015), for instance, compared classical transformational leadership and health-oriented leadership, finding considerable differences in stress recovery processes.

The business software developers are providing significant support in developing and digitalizing BE. For example, SAP (Fauscette, 2014) develops high performance platforms for suppliers and procurement professionals to build collaborative relationships. IBM (Rometty, 2013) creates support for the development of smart organizations, while Salesforce connects companies and customers (Payne \& Frow, 2005). Yet no matter how complex these tools are, they cannot reflect the complexity of the systems they should manage.

Software developers possess knowledge of business operations. Access to cloud-stored business data gives them an opportunity to evolve to a new meta-level. They can become business integrators, providing companies with services to instantly identify appropriate business partners and manage business partners' related processes effortlessly, significantly affecting the communication processes (Bregman, Peng, \& Chin, 2015; Fauscette, 2014).

Regulators form and enforce rules under which the players execute their activities. Their role in the systemic sense is to support positive processes and omit the use of negative ones. Although players usually experience them through their repressing instruments (Beyer, Cohen, Lys, \& Walther, 2010; King, Lenox, \& Terlaak, 2005), they are responsible for the success of the whole ecosystem, its internal structure, and effects on other ecosystems. Cancer, Rebernik, and Knez-Riedl (2013) proposed methods for assessing the environmental reputation and the creation of new sets of values.

Attempts have been made to address the BE management issues requisitely holistically using diverse approaches. Razavi, Moschoyiannis, and Krause (2009) proposed a peerto-peer network design that aims to support business activities conducted through a network of collaborations that generate value. We agree that some technologies can help optimize BE; nevertheless, to maximize the positive technological effect the $\mathrm{BE}$, properties must undergo a systemic investigation.

\subsection{System research}

Systems and their viability have been defined by many researchers. The systemic view was provided by cybernetics, where Beer (1972) introduced the Viable System Model (VSM), based on biological and psychological observations and the Ashby's law of requisite variety.

Figure 1. The simplified organizational VSM

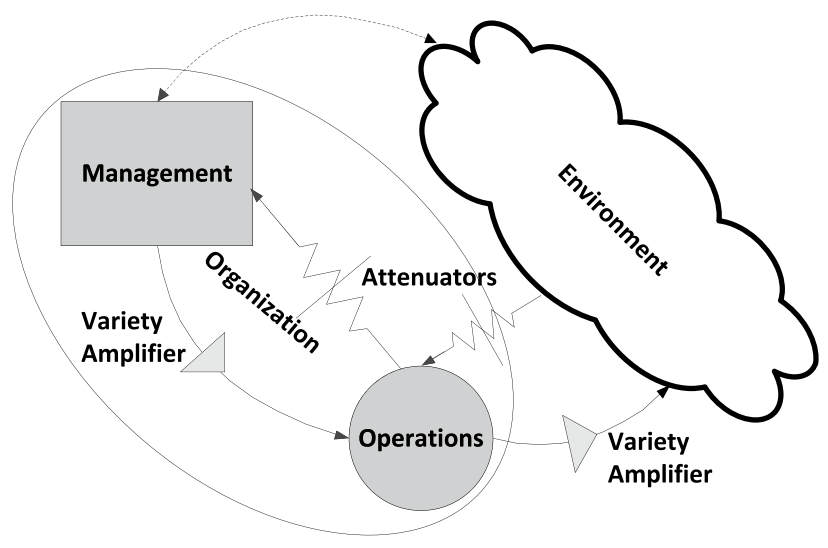

Adapted from (Beer, 1985)

Waelchli (1989) explained the relationships with the environment in VSM using a simplified version of the model (see Figure 1). The organizational components were reduced to management (in the rectangle) and Operations (in circle): Management regulates Operations, and Operations regulates 
the environment. The viability of the system is supported by massive flows of information within the organization as well as between the organization and the environment. The main focus of the VSM is designing methods to transmit and manage very large amounts of information in real time. In Figure 1, the information communication channels, represented by arrows, interlock elements of the Organization (Management and Operations) and link the Organization to the Environment.

Researchers have proposed using systemic tools, such as system dynamics to help manage complex environments. Bianchi (2002) emphasized the need for a learning-oriented approach to planning and control as a prerequisite for SMEs' survival and growth. Oyebisi, Momodu, and Olabode (2013) compared models for managing a technological innovation system (TIS), defined drawbacks of conventional models, and proposed the use of system dynamic models as a valid solution. They all pointed out that potent modeling and simulation software and knowledge in multiple domains are required for successful modeling.

Limiting business information to financial or marketing information has been strongly challenged. Systemic thinking and requisite holism are a valid basis for innovation (Mulej \& Potocan, 2007; Zenko \& Mulej, 2011). It is insufficient to design processes by ignoring the information that cannot be attained by the current state of technology. We followed the advice to expand the observed data and use BD resources to get a step closer to a higher BE meta level.

\section{Business Ecosystems Players}

Rich BE provide an environment for multiple players with high diversity (Gao et al., 2013; Moore, 1993; Nachira, Dini, \& Nicolai, 2013). In this section, we elaborate on the objectives and strategies of five BE players greatly affected by BD technologies: individuals, SMEs, large organizations, information providers, and regulators. The business players selection is based on Moore's (1993) definition of the business ecosystems and upgraded with information providers and regulators, which play an important role in the viable system perspective (Espejo, Bowling, \& Hoverstadt, 1999).

For every player, a question arises: How can I exploit the available BE resources for individual growth and, more importantly, what do I need to invest into it to do it in the future? The answer depends on the individual strategies, which range from focusing on the short-term success to breaking down the ecosystem defense barriers and exploiting the system resources as well as taking a leadership role and generating sustainable resources needed for the other ecosystem members to survive. Independent of the decision about what role to play, the individual depends on information concerning other players.

Although BD affects players on multiple fields of attack (Cukier, 2014; McAfee \& Brynjolfsson, 2012; Press, 2013; Zhang et al., 2014), we narrowed the field of identified topics identified to five influential topics that will identify opportunities and threats for BE players: individual marketing, health treatment, work opportunities, financial services, and security enforcement. The reduction criterion is based on a preliminary keyword analysis conducted in Google and Google Scholar. Selected topics related to "Big Data" achieved an average of 55,900 results in research-related contents and 48-900,000 in a general search.

To preserve the required level of standard deviation in model transparency, only the most important strategies are displayed. This results in hiding the direct feedback loops. Nevertheless, when observing from a distance, some of the most important system level loops ranging among multiple players can be identified. For instance, individuals receive protection from organizations and information providers by the regulators.

\subsection{Individuals}

Individuals are usually anonymized as customers or roles in organizations (Drucker, 2002; Dunkl et al., 2015). Nevertheless, if compared to the biological ecosystems, they play the role of cells with the special ability to stand alone or group with others to form an organization (Ajzen, 1991; Waelchli, 1989). Individuals actually run all the players in the ecosystem. Thus, every role-no matter how important-is designed to be executed by an individual. The question is, why do we not treat them as individuals? One of the obvious reasons is that it is exceedingly hard to follow the behavior of individuals and even harder to predict their actions while simultaneously not violating their personal integrity (Nelson, 1970; Zhang et al., 2014).

Individual objectives are highly volatile; they change over time and adapt to situations. Sometimes they are conflicting. For instance, they like autonomy in driving a car, but are averse to taking responsibility. The duality regarding BD technologies is that they like receiving customized services, but do not want to share uncensored personal data (Zhang et al., 2014).

Table 1 presents opportunities and threats to individuals for the selected BD domain. For opportunities, strategies on how to achieve them are represented; on the threat side, mitigation strategies are explained. 
Table 1. BD Individual-related Opportunities and Threats and Strategies Used

\begin{tabular}{|c|c|c|}
\hline BD domain & Opportunity & Threat \\
\hline Individual marketing & $\begin{array}{l}\text { Receive customized offers, potentials of } \\
\text { choosing best-suited deals. }\end{array}$ & $\begin{array}{l}\text { Becoming a target of marketing harassment, } \\
\text { trading with individual data. }\end{array}$ \\
\hline Strategies & $\begin{array}{l}\text { Sharing data on their properties, preferences, } \\
\text { and activities. }\end{array}$ & $\begin{array}{l}\text { Relying on the system protection. Sharing data } \\
\text { with trusted players, limiting data content, } \\
\text { protecting from undesired listening, rejecting } \\
\text { unwanted messages. }\end{array}$ \\
\hline Health treatment & $\begin{array}{l}\text { Individual diagnosis and treatment propositions } \\
\text { based on group knowledge. }\end{array}$ & Misuse of individual medical data. \\
\hline Strategies & $\begin{array}{l}\text { Continually sharing medical data, using } \\
\text { predictive models results. }\end{array}$ & $\begin{array}{l}\text { Anonymization of shared data, audited data } \\
\text { entry and data access. }\end{array}$ \\
\hline Work opportunities & Finding perfect engagement. & $\begin{array}{l}\text { Disclosure of job-seeking activities, deceiving } \\
\text { job offers. }\end{array}$ \\
\hline Strategies & $\begin{array}{l}\text { Searching for work opportunities that match my } \\
\text { properties and offer desired rewards. }\end{array}$ & $\begin{array}{l}\text { Active management of data privacy, checking } \\
\text { the employee reputation. }\end{array}$ \\
\hline Financial services & Access to investment and funding opportunities & Fraud and default risks. \\
\hline Strategies & $\begin{array}{l}\text { Using tools for accessing inexpensive funding } \\
\text { and profile-adjusted investments. }\end{array}$ & $\begin{array}{l}\text { Using investment services with integrated fraud } \\
\text { prediction. }\end{array}$ \\
\hline Security enforcement & $\begin{array}{l}\text { Using system security measures for a desired } \\
\text { environment safety level. }\end{array}$ & Control misuse. \\
\hline Strategies & $\begin{array}{l}\text { Using available system services and resources, } \\
\text { sharing data when observed. }\end{array}$ & $\begin{array}{l}\text { Using legislation to protect individual rights, } \\
\text { using social communities to control security } \\
\text { organizations. }\end{array}$ \\
\hline
\end{tabular}

Source: Author's own data

BD technologies focus not only on individuals, but also try to collect data on their activities. Generally, this can have great positive effects on the usability of the services offered to an individual in an instance; on the other hand, this information can be used to harm the individual and exploit his/her potential weaknesses. Individuals can support the positive effects by sharing information, but they need system-generated protection to prevent undesired behavior by other players.

\subsection{SMEs}

SMEs operate on limited resources; consequently, they use external resources and a narrow set of products and services for a limited market (Barney, 1991). Their viability depends on the capacity to adjust to properties of the $\mathrm{BE}$ (Beer, 1972). Because of their abundant numbers and the enthusiasm of the involved individuals, they are considered the most important innovation force (Zenko \& Mulej, 2011) and a major BE producer (E._C._European_Commission, 2004). In their domain, SMEs actively research and develop new approaches that will provide them enough resources. In other domains. they use existing state-of-the-art services.

As depicted in Table 2, SMEs in all business domains use BD services to optimize the exploitation of their business environment and expand their influence. These services are used as a plug-and-play appliance to minimize the costs of new activities. SMEs typically face two kinds of threats: the active role of their competition and the disclosure of their behavior.

\subsection{Large organizations}

Large organizations have major influence in the local or global ecosystem (Beer, 1985; Davenport, 1998). In their domains (such as car manufacturing, energy providers, and pharmacy), they actively coordinate other players in the system. Large organizations include companies, public organizations such as hospitals, research organizations, educational organizations, and others. They possess the resources to lead big projects expecting long-term results (Moore, 1993); they systematically scan for promising solutions and adapt them to fit their needs. On the other hand, their adoption rate to changes in the ecosystem is rather slow.

Large organizations want to increase their influence and actively change their environment. To this end, they invest heavily in their domain-related research, and they go beyond using state-of-the-art toolsets and actively participate in their development until they fit their needs.

Large organizations use active participation in harnessing BD-related opportunities (see Table 3). They use BD technologies to gather more detailed data (for instance, using sensor data) or acquire data from their environment (such 
as global medical data). They also actively participate in data analysis research to develop tailored BD-based tools (for instance, social media-based profiling in the employment-recruiting process).

Table 2. BD SMEs' Related Opportunities and Threats and Strategies Used

\begin{tabular}{|c|c|c|}
\hline BD domain & Opportunity & Threat \\
\hline Individual marketing & $\begin{array}{l}\text { Reach existing and new customers, with high } \\
\text { selling potential. }\end{array}$ & $\begin{array}{l}\text { Losing customer trust or being replaced by the } \\
\text { competition. }\end{array}$ \\
\hline Strategies & $\begin{array}{l}\text { Combining classic marketing methods with } \\
\text { outsourced services, offered by information } \\
\text { providers. }\end{array}$ & $\begin{array}{l}\text { Focusing on the customers, willing to accept } \\
\text { marketing actions, providing them a real value } \\
\text { added. }\end{array}$ \\
\hline Health treatment & $\begin{array}{l}\text { Using BD-based diagnosis and treatment } \\
\text { selection services for their patients. }\end{array}$ & $\begin{array}{l}\text { Potential of missuses by pharmaceutical } \\
\text { companies. }\end{array}$ \\
\hline Strategies & $\begin{array}{l}\text { Using existing predictive models based } \\
\text { on medical BD on individual symptoms to } \\
\text { determine diagnosis and treatment. }\end{array}$ & $\begin{array}{l}\text { Using generally acknowledged information } \\
\text { sources, involving organizations with high } \\
\text { reputation. }\end{array}$ \\
\hline Work opportunities & Acquiring employees fitting the position. & Dishonest applicant information. \\
\hline Strategies & $\begin{array}{l}\text { Comparing the position requirements with the } \\
\text { candidate properties. }\end{array}$ & Automatic profile assessment. \\
\hline Financial services & $\begin{array}{l}\text { Global direct investment and funding } \\
\text { opportunities. }\end{array}$ & Fraud and default risks. \\
\hline Strategies & $\begin{array}{l}\text { Using services for finding the most appropriate } \\
\text { P2P funding, building low-level risk reputation. }\end{array}$ & $\begin{array}{l}\text { Using investment services with integrated fraud } \\
\text { prediction. }\end{array}$ \\
\hline Security enforcement & Attaining a desired safety level. & Total control. \\
\hline Strategies & $\begin{array}{l}\text { Using system information services to gain data } \\
\text { on business partners' security risks. }\end{array}$ & Avoiding control or automatic reporting. \\
\hline
\end{tabular}

Source: Author's own data

Table 3. BD Large Organizations' Related Opportunities and Threats and Strategies Used

\begin{tabular}{|c|c|c|}
\hline BD domain & Opportunity & Threat \\
\hline Individual marketing & $\begin{array}{l}\text { Retain existing customers, gain market shares, } \\
\text { and access new markets more efficiently. }\end{array}$ & $\begin{array}{l}\text { Not understanding the needs of customers, } \\
\text { using wrong communication channels, sending } \\
\text { wrong messages }\end{array}$ \\
\hline Strategies & $\begin{array}{l}\text { In-house data analysis, accessing external } \\
\text { data for data mining, actively cooperating with } \\
\text { information providers. }\end{array}$ & $\begin{array}{l}\text { Analyzing the content and volume of } \\
\text { communication, used by the targeted groups of } \\
\text { customers, and adapting to their patterns. }\end{array}$ \\
\hline Health treatment & $\begin{array}{l}\text { Design systems that use existing knowledge for } \\
\text { diagnosis and treatment selection. }\end{array}$ & $\begin{array}{l}\text { Forcing selling of selected products, resulting } \\
\text { in suboptimal medical treatment. }\end{array}$ \\
\hline Strategies & $\begin{array}{l}\text { Active cooperation in data design and } \\
\text { knowledge extraction. }\end{array}$ & $\begin{array}{l}\text { Building reputation, combining clinical results } \\
\text { of healing substances produced by competing } \\
\text { producers. }\end{array}$ \\
\hline Work opportunities & Acquiring employees fit for the position. & Dishonest applicant information. \\
\hline Strategies & $\begin{array}{l}\text { Designing support for comparative analysis of } \\
\text { a candidate's potential and the tasks laid out } \\
\text { for him. }\end{array}$ & Profiling applicant data. \\
\hline Financial services & $\begin{array}{l}\text { Managing investment portfolio and using } \\
\text { inexpensive funding resources, financing } \\
\text { customers. }\end{array}$ & Fraud and default risks \\
\hline Strategies & $\begin{array}{l}\text { Using predictive analytics on investments, } \\
\text { attracting low-risk investors. }\end{array}$ & $\begin{array}{l}\text { Supporting the developments of fraud } \\
\text { prediction models }\end{array}$ \\
\hline Security enforcement & $\begin{array}{l}\text { Designing a safe environment to conduct global } \\
\text { operations. }\end{array}$ & $\begin{array}{l}\text { Contra intelligence of players in external } \\
\text { systems. }\end{array}$ \\
\hline Strategies & $\begin{array}{l}\text { Algorithms for identifying localized threats } \\
\text { based on behavior analysis and social contacts. }\end{array}$ & $\begin{array}{l}\text { Data security measures, protecting the } \\
\text { knowledge of behavioral analytics. }\end{array}$ \\
\hline
\end{tabular}

Source: Author’s own data 


\subsection{Information providers}

$\mathrm{BD}$ and cloud computing are responsible for the emergence of highly innovative new companies or the reorganization of companies with a long tradition of delivering information (rating agencies, registers, ERP providers, etc.). Information providers use their knowledge on how to access data, store data, blend data (publicly available, internal or restricted, social media, sensor-generated data, etc.), and analyze data to create services and products for other BE players. As they possess data from multiple sources and the knowledge to process it, they can actively use it to upgrade providing services to a new meta level, thereby becoming business integrators, financial intermediators, or service coordinators.

One of the common questions arising is whether the business partner will deliver. The most common strategy for predicting future behavior in a situation is using the knowledge of the masses. In the BD domains presented in Table 4, data on individual behavior are blended from multiple sources: In individual marketing, it is social media, sales, and localization data whereas in health treatment, data from diagnostic apparatuses are combined with medical records. BD projects are executed in cooperation with organizations or, as in the case of security enforcement, regulators.
Threats are often connected with the change of transparency in the system that information providers deliver. On one hand, all players would like a higher level of transparency of the system around them; on the other hand, they would like to conceal their potentially depraved behavior.

\subsection{Regulators}

Regulators' mission is to ensure that the desired processes in their regulation domain are executed efficiently and prevent undesired events. They do this by providing support, rules, and control mechanisms for the players' behavior. They consider players' viability, the level of activity in the system, and the system effects to the environment (Prosser, 1997; Warhurst, 2005). For instance, in the financial services domain, national and EU central banks provide rules and execute control in the form of constant reporting, but they regulate finance resources' prices and provide the required funds for the financial institutions to function (Beyer et al., 2010). For the regulators to act proactively, they need to measure activities and recognize the effects of desired and undesired behavior in the system (e.g., financial institutions are reporting to central banks for stress testing).

Table 4. BD Information Providers' Related Opportunities and Threats and Strategies Used

\begin{tabular}{|c|c|c|}
\hline BD domain & Opportunity & Threat \\
\hline Individual marketing & $\begin{array}{l}\text { Offer data and services for identifying and } \\
\text { sending customized offers to customers. } \\
\text { Adapting a new role of market integrator. }\end{array}$ & $\begin{array}{l}\text { Being accused of marketing harassment and } \\
\text { trading with individual data. }\end{array}$ \\
\hline Strategies & $\begin{array}{l}\text { Predicting future individual customer desires } \\
\text { based on BD associative data mining. Designing } \\
\text { new cooperative channels. }\end{array}$ & $\begin{array}{l}\text { Following the system rules that enable sharing } \\
\text { of personal data to referenced players, applying } \\
\text { control mechanisms, respecting the individual } \\
\text { integrity, preventing misuse by their customers. }\end{array}$ \\
\hline Health treatment & $\begin{array}{l}\text { Diagnosis and treatment proposition based on } \\
\text { group knowledge }\end{array}$ & Sharing individual medical data \\
\hline Strategies & $\begin{array}{l}\text { Designing predictive data-mining models for } \\
\text { understanding patients based on knowledge } \\
\text { stored in clinical BD. }\end{array}$ & $\begin{array}{l}\text { Anonymization of shared data, audited data entry } \\
\text { and data access. }\end{array}$ \\
\hline Work opportunities & $\begin{array}{l}\text { Connecting job seekers with potential } \\
\text { employers. }\end{array}$ & $\begin{array}{l}\text { Lack of discretion, dishonesty of job seekers and } \\
\text { employees. }\end{array}$ \\
\hline Strategies & $\begin{array}{l}\text { Design global and local comparative analysis of } \\
\text { job offers and profile data algorithms. }\end{array}$ & $\begin{array}{l}\text { Developing data security measures and } \\
\text { reputation models. }\end{array}$ \\
\hline Financial services & Connecting investors and loan receivers. & Fraud and default risks \\
\hline Strategies & $\begin{array}{l}\text { Developing algorithms for finding the most } \\
\text { appropriate peer-to-peer funding. }\end{array}$ & $\begin{array}{l}\text { Developing fraud prediction algorithms and } \\
\text { reputation analysis services. }\end{array}$ \\
\hline Security enforcement & $\begin{array}{l}\text { Providing methods of gathering, storing and } \\
\text { analyzing BD. }\end{array}$ & Data leakage, data analysis methods' leakage. \\
\hline Strategies & $\begin{array}{l}\text { Developing new communication channels, BD } \\
\text { storages, multimedia analysis, threat detection } \\
\text { models. }\end{array}$ & $\begin{array}{l}\text { Data security measures, protecting the } \\
\text { knowledge on BD methods. }\end{array}$ \\
\hline
\end{tabular}

Source: Author's own data 
Table 5. BD Regulators' Related Opportunities and Threats and Strategies Used

\begin{tabular}{|c|c|c|}
\hline BD domain & Opportunity & Threat \\
\hline Individual marketing & $\begin{array}{l}\text { Market optimization, reduced communication } \\
\text { noise between the system players, better } \\
\text { coordination between supply and demand. }\end{array}$ & $\begin{array}{l}\text { Examples of marketing harassment, especially on } \\
\text { players with low protection barriers }\end{array}$ \\
\hline Strategies & $\begin{array}{l}\text { Designing protocols for individual marketing, } \\
\text { redesigning rules and support mechanisms } \\
\text { by involving all players on the market. Design } \\
\text { methods for continuous rule redesign process. }\end{array}$ & $\begin{array}{l}\text { Using BD exception identification technologies } \\
\text { to redesign system level rules and control } \\
\text { mechanisms. }\end{array}$ \\
\hline Health treatment & $\begin{array}{l}\text { Creating a global knowledge-based medical } \\
\text { system. }\end{array}$ & Sharing individual medical data. \\
\hline Strategies & $\begin{array}{l}\text { Designing protocols for safe medical data } \\
\text { sharing, predictive data mining based on } \\
\text { comparing the instance data with shared data } \\
\text { pool. }\end{array}$ & $\begin{array}{l}\text { Forming rules and creating control mechanisms } \\
\text { on a system level for anonymization of shared } \\
\text { data, audited data entry and data access. . }\end{array}$ \\
\hline Work opportunities & $\begin{array}{l}\text { Creating a transparent, secure environment for } \\
\text { individuals and employees. }\end{array}$ & Indiscreet behavior, not fulfillment of obligations. \\
\hline Strategies & $\begin{array}{l}\text { Registration and validation of activities in the } \\
\text { job-seeking and evaluation system. }\end{array}$ & $\begin{array}{l}\text { Developing tools to build and express reputation } \\
\text { of individuals and organizations. }\end{array}$ \\
\hline Financial services & Design and manage fluid financial markets. & $\begin{array}{l}\text { Prevent liquidity shortage or overflow, manage } \\
\text { and mitigate risks. }\end{array}$ \\
\hline Strategies & $\begin{array}{l}\text { Co-design and manage new financing and } \\
\text { investment models. Financial needs prediction } \\
\text { model. }\end{array}$ & $\begin{array}{l}\text { Design investment activities, demand and supply } \\
\text { and projects' default rate of predictive analytics. }\end{array}$ \\
\hline Security enforcement & $\begin{array}{l}\text { Preventing undesired behavior of system and } \\
\text { external players. }\end{array}$ & Misuse of security enforcement toolset. \\
\hline Strategies & $\begin{array}{l}\text { Forming dynamic rules and control } \\
\text { mechanisms for identifying and mitigating } \\
\text { undesired behavior based on all available data, } \\
\text { exception analytics and behavior predictions. }\end{array}$ & $\begin{array}{l}\text { Developing control systems over protocol } \\
\text { execution and delivering them to the system } \\
\text { players. }\end{array}$ \\
\hline
\end{tabular}

Source: Author's own data

Regulators use BD technologies' potentials (Table 5) to optimize players' interactions and use of the resources, provide a higher level of transparency in the system, and predict future interactions. To address threats to the weakest players in the system in the form of marketing harassment or indiscreet behavior, regulators use $\mathrm{BD}$ technologies to design a more transparent environment and elaborate on the reputation qualities. In terms of security enforcement, they use similar strategies as do organizations to profile their partners, but they do it on a larger scheme. Regulators can only be successful by recognizing the power of all of the participants in the system.

\section{BD System Impact}

In this section, the five players' strategies are presented, addressing opportunities and threats. To create a system overview, the effects of players' strategies in relation to the other players' strategies are visualized. This will help us support the potential cooperation among players, eliminate threats, and achieve a win-win-win situation.
Figure 2 presents a highly simplified model of the effects BD have on the BE players, and their responses are provided. For every combination of five players and five BD domains, only one opportunity and one threat are represented. In addition, only one player's strategy is selected for every one of these. To preserve the minimal state of readability, the effects of a player's strategies with other players' strategies are not displayed. Positive (or supporting) flows are marked with "+” and negative (mitigation) ones are marked with “-”.

Individuals are the main source of data. At the same time, end users - either of BD results or of products and servicestailor their resources to their desires with the help of BD. They are the most vulnerable group as they are threatened by marketing harassment, data trading, misuse, and disclosure. Interestingly, they are positioned at the opposite side of the information providers, assessing the relationships among these entities as relatively weak. Because the regulators' strategies are primarily focused on mitigating threats toward them, they are positioned in their vicinity.

A high level of overlap exists in opportunities and threats for SMEs and large organizations, ranging from reach existing 
and new customers to total control of the system. Nevertheless, their strategies differ considerably. SMEs tend to use newly developed BD-based tools and services whereas large organizations co-develop these in their domains of interest. For instance, to reach better diagnosis and treatment selection, SMEs (e.g., practicing doctor offices) will use existing predictive models whereas large organizations (e.g., clinical centers and pharmaceutic companies) actively cooperate in data and algorithm design. They also share threats (losing trust, fraud, and default risks). Their strategies range from building up their reputation to the development and use of fraud prediction models.

Information providers' strategies are highly correlated with large organizations' strategies. They use organizations to blend data from multiple sources and deliver results to individuals-again through organizations (development of peerto-peer algorithms to connect investors and loan receivers). Because of their knowledge of multiple domains, they tend to integrate multiple domains, such as marketing, sales, and finance, where they correlate with the regulators' objectives of coordinating the players.

The role of the information providers has significantly increased as they provide services to all players in the system and redesign domain processes. Thus, information providers' initiatives should be closely monitored by the regulators and above all by the public initiatives of individuals.

Regulators play a two-sided role: First, they rearrange the ecosystem processes to achieve a higher level of optimization; second, they provide system protection for the vulnerable players. The regulators' optimization efforts (market optimization, better coordination, fluid financial markets) provide guidelines for information providers. The protective side of the regulators is highly connected with the threats to individuals (marketing harassment, data trading, misuse, and disclosure) and organizations (losing trust, fraud, and default risks). To execute strategies to prevent threats (e.g., sharing rules and control mechanisms, building reputation, using predictive analytics), they include and co-design products and services offered by the information providers.

Monitoring individual actions and generating a smart reputation can create a major shift in cooperation. It may provide worldwide personal reputation transparency and provide a way for individuals to act socially responsibly. This will not only change business behavior, but will also affect all parts of the society.

On the negative side, BD will raise considerable privacy and security issues for individuals and organizations. It will redefine business secrets and fundamentally challenge individuals' privacy rights. Lowering organizational and personal independence will increase the possibility of rapid misinformation dispersion.

\section{Discussion and Conclusion}

$\mathrm{BD}$ promises to be a disrupting technology, facilitating significant changes. In the $\mathrm{BD} R \& D$ community, many efforts have been focused on storing and integrating large quantities of rapidly changing data with a high variety in form and content. Some focus has been put into supporting new ways of collaborations, predictions, and advanced user experiences. Although some researchers follow a requisitely holistic vision in the effort to create smart environments, most efforts focus on resolving partial issues.

It is hard to gain an appropriate perspective on the impact. An overly schematic view obscures all the important details and provides no value added or reference. A detailed view is too crowded and prohibits seeing the forest because of the trees. To provide a (somewhat) transparent view and still display important details, we used system analysis to achieve a visualization repository, displaying only the most important entities that occur in a selected viewpoint. We decided to include a limited number of players (5), BD domains (5), opportunities and threats (one of each for every BD domain and a player combination), and strategies to use the opportunities and mitigate threats (one for every opportunity and threat). The selection of the appropriate representatives is based on the literature reviewed.

The system of creating an overview is twofold. In step one, for every player in the system, its objectives, BD domains, related opportunities, threats, and strategies are scripted. This provides a brief profile of a player, his motivation, and resources he is capable or willing to engage when facing changes in his environment. In the second step, a system dynamic diagram is used to provide an overview of all the involved entities. The visualization of relationships among entities provides the desired overview effect and simultaneously gives information on particular strategies involved in reaching particular players' objectives.

This paper delivers important insights for multiple R\&D communities. For BE designers and policymakers, it provides a tool to overview intersections of BE players and $\mathrm{BD}$ domains. It helps BD architects recognize the potentials their services offer to the players and threats they need to help preventing. It helps business managers direct organizations' development to fully exploit the BD potentials. Finally, it helps individuals actively influence the development of society and build their reputation. 
Figure 2. The system dynamics diagram of BD opportunities, threats, objectives, and strategies

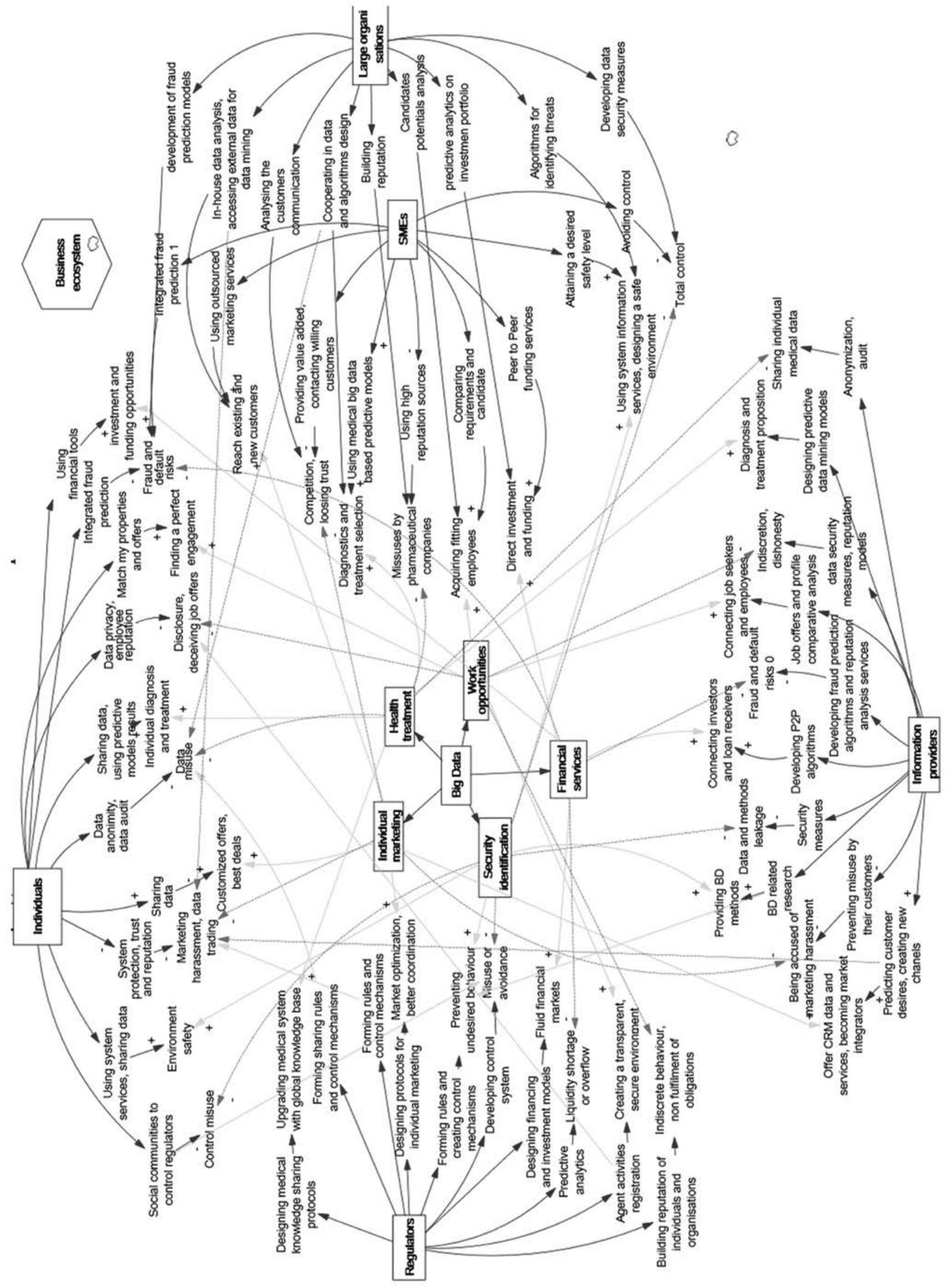

Source: Author’s own data 
This paper has provided a restricted view of the system. To generate a better BE-BD map, multiple limitations should be surmounted. It is hard to condense the system complexity: the players, their relationships, and strategies over time for entire populations at the instance level and the predictions based upon BD in a standard research paper, formatted for a static (even printed) version.

Thus, two paths should be followed. The first relates to the research scope. In terms of all the important relationships and strategies, we need to focus on the single instance-a single strategy that needs to be described in detail- to discover its complexity and its impact on the system entities and then connect them in a holistic map. The second involves a dynamic, highly visual communication channel for distributing the research results, capable of representing the research models' full complexity that goes well beyond current scientific journals' formats.

\section{References}

1. Ajzen, I. (1991). The theory of planned behavior. Organizational Behavior and Human Decision Processes, 50(2), 179-211. http://dx.doi. org/10.1016/0749-5978(91)90020-T

2. Barney, J. (1991). Firm resources and sustained competitive advantage. Journal of Management, 17(1), 99-120. http://dx.doi. org/10.1177/014920639101700108

3. Beer, S. (1972). Brain of the Firm. London: The Penguin Press.

4. Beer, S. (1985). Diagnosing the system for organisation. Chrichester: John Wiley.

5. Beyer, A., Cohen, D. A., Lys, T. Z., \& Walther, B. R. (2010). The financial reporting environment: Review of the recent literature. Journal of Accounting \& Economics, 50(2-3), 296-343. http://dx.doi.org/10.1016/j.jacceco.2010.10.003

6. Bianchi, C. (2002). Introducing SD modelling into planning and control systems to manage SMEs' growth: a learning-oriented perspective. System Dynamics Review, 18(3), 315-338. http://dx.doi.org/10.1002/sdr.258

7. Bregman, R., Peng, D. X., \& Chin, W. (2015). The effect of controversial global sourcing practices on the ethical judgments and intentions of US consumers. Journal of Operations Management, 36, 229-243. http://dx.doi.org/10.1016/j.jom.2015.01.001

8. Bryant, E. Randal, Katz, H. Randy, \& Lazowska, D. Edward. (2008). Big-Data Computing: Creating revolutionary breakthroughs in commerce, science, and society. http://cra.org/ccc/wp-content/uploads/sites/2/2015/05/Big_Data.pdf

9. Cancer, Vesna, Rebernik, Miroslav, \& Knez-Riedl, Jozica. (2013). The environmental creditworthiness assessment methodology/ Metodologija presojanja okoljske bonitete. Nase Gospodarstvo : NG, 59(1/2), 66-74.

10. Cukier, Kenneth (2014). Big Data and the Future of Business. In F. González (Ed.), Reinventing Company in the Digital Age: BBVA. Retrieved from https://www.bbvaopenmind.com/en/article/big-data-and-the-future-of-business/.

11. Davenport, T. H. (1998). Putting the enterprise into the enterprise system. Harvard Business Review, 76(4), 121-131.

12. Drucker, F. Peter. (2002). They're not employees, they're people. Harvard Business Review, 80(2), 70-77.

13. Dunkl, Anita, Jiménez, Paul, Zizek, Simona Sarotar, Milfelner, Borut, \& Kallus, Wolfgang K. (2015). Similarities and Differences of Health-promoting Leadership and Transformational Leadership. Nase Gospodarstvo : NG, 61(4), 3-13.

14. E._C._European_Commission. (2004). Observatory of European SMEs: Internationalization of SMEs. Brussels: EC.

15. Espejo, R., Bowling, D., \& Hoverstadt, P. (1999). The viable system model and the Viplan software. Kybernetes, 28(6-7), 661-678. http://dx.doi.org/10.1108/03684929910282944

16. Evans, Philip. (2014). From Deconstruction to BigData: How technology is reshaping the corporation. In F. González (Ed.), Reinventing Company in the Digital Age BBVA. Retrieved from https://www.bbvaopenmind.com/en/article/from-deconstruction-to-big-data-how-technology-is-reshaping-the-corporation/.

17. Fauscette, Michael. (2014). Business Networks: The Next Wave of Innovation. https://go.sap.com/docs/download/2014/12/14c7ef1e127c-0010-82c7-eda71af511fa.pdf

18. Frohlich, M. T., \& Westbrook, R. (2001). Arcs of integration: an international study of supply chain strategies. Journal of Operations Management, 19(2), 185-200. http://dx.doi.org/10.1016/S0272-6963(00)00055-3

19. Gao, Ruize, Zhang, Zhenji, Tian, Zhihong, Guan, Xiaolan, \& Li, Ang. (2013). Modelling the Emergence and Evolution of e-Business Ecosystems from a Network Perspective. Studies in Informatics and Control, 22(4), 339-348.

20. Hellstrom, Magnus, Tsvetkova, Anastasia, Gustafsson, Magnus, \& Wikstrom, Kim. (2015). Collaboration mechanisms for business models in distributed energy ecosystems.Journal of Cleaner Production, 102,226-236. http://dx.doi.org/10.1016/j.jclepro.2015.04.128

21. King, A. A., Lenox, M. J., \& Terlaak, A. (2005). The strategic use of decentralized institutions: Exploring certification with the ISO 14001 management standard. Academy of Management Journal, 48(6), 1091-1106. http://dx.doi.org/10.5465/AMJ.2005.19573111

22. Lämmel, Ralf. (2008). Google's MapReduce programming model - Revisited. Science of Computer Programming, 70(1), 1-30. http:// dx.doi.org/10.1016/j.scico.2007.07.001

23. Lane, D. C. (2000). Should system dynamics be described as a 'hard' or 'deterministic' systems approach? Systems Research and Behavioral Science, 17(1), 3-22. http://dx.doi.org/10.1002/(SICI)1099-1743(200001/02)17:1<3::AID-SRES344>3.0.C0;2-7 
Igor Perko, Peter Ototsky: Big Data for Business Ecosystem Players

24. Mavric, Jasmina, Tominc, Polona, \& Bobek, Vito. (2014). Qualitative indicators for measuring the performance development of selected cities/Kvalitativni indikatorji merjenja uspesnosti razvoja izbranih mest. Nase Gospodarstvo : NG, 60(3/4), 13-25.

25. McAfee,A., \& Brynjolfsson, E. (2012). Strategy \& competition Big Data:The Management Revolution. Harvard Business Review, 90(10), 60-68.

26. Moore, J. F. (1993). Predators and prey - a new ecology of competition. Harvard Business Review, 71(3), 75-86.

27. Mulej, M., \& Potocan, V. (2007). Requisite holism - precondition of reliable business information. Kybernetes, 36(3-4), 319-332. http:// dx.doi.org/10.1108/03684920710746986

28. Nachira, Francesco, Dini, Paolo, \& Nicolai, Andrea. (2013). Digital Business Ecosystems Retrieved from http://www.digital-ecosystems. org/book/DBE-2007.pdf

29. Nelson, P. (1970). INFORMATION AND CONSUMER BEHAVIOR. Journal of Political Economy, 78(2), 311-329. http://dx.doi. org/10.1086/259630

30. Oyebisi, Timothy O., Momodu, Abiodun S., \& Olabode, Segun O. (2013). System thinking in managing technological innovation systems in manufacturing companies/Sistemsko razmisljanje pri upravljanju tehnoloskega informacijskega sistema v proizvodnih podjetjih. Nase Gospodarstvo : NG, 59(3/4), 50-57.

31. Payne, A., \& Frow, P. (2005). A strategic framework for customer relationship management. Journal of Marketing, 69(4), $167-176$. http://dx.doi.org/10.1509/jmkg.2005.69.4.167

32. Press, Gil. (2013). A Very Short History Of Big Data. Forbes/tech. http://www.forbes.com/sites/gilpress/2013/05/09/a-very-shorthistory-of-big-data/

33. Prosser, Tony. (1997). Law and the regulators. Oxford: Oxford unvierity press.

34. Razavi, A., Moschoyiannis, S., \& Krause, P. (2009). An open digital environment to support business ecosystems. Peer-to-Peer Networking and Applications, 2(4), 367-397. http://dx.doi.org/10.1007/s12083-009-0039-5

35. Korez-Vide, Romana. (2004). Uncertainties of Measuring Globalisation. Nase Gospodarstvo : NG, 50(1,2), 46-51.

36. Rometty, Ginni. (2013). A New Era of Smart. https://www.youtube.com/watch?t=19\&v=iNZj38sD81w

37. Tomlin, B. (2006). On the value of mitigation and contingency strategies for managing supply chain disruption risks. Management Science, 52(5), 639-657. doi: 10.1287/mnsc.11060.0515

38. Umpleby, Stuart, \& Lim, Lucy. (2007). The spread of management ideas and methods around the world/Razsirjenost menedzerskih idej in metod po svetu. Nase Gospodarstvo : NG, 53(3/4), 124-135.

39. Waelchli, Fred (1989). the VSM and Ashby's law as illuminants of historical management thought. In R. Espejo (Ed.), The Viable system model : interpretations and applications of Stafford Beer's VSM: Willey.

40. Waller, M. A., \& Fawcett, S. E. (2013). Data Science, Predictive Analytics, and Big Data:A Revolution That Will Transform Supply Chain Design and Management. Journal of Business Logistics, 34(2), 77-84. http://dx.doi.org/10.1111/jbl.12010

41. Warhurst, A. (2005). Future roles of business in society: the expanding boundaries of corporate responsibility and a compelling case for partnership. Futures, 37(2-3), 151-168. http://dx.doi.org/10.1016/j.futures.2004.03.033

42. Wood, David. (2010). Linking Enterprise Data (D. Wood Ed.): Springer science+Business Media. http://dx.doi.org/10.1007/978-1-44197665-9

43. Zenko, Zdenka, \& Mulej, Matjaz. (2011). Innovating measurement of economic success for more accurate information/Inoviranje merjenja ekonomskega uspeha za bolj ustrezne informacije. Nase Gospodarstvo : NG, 57(5/6), 11-19.

44. Zhang, Yin, Chen, Min, Mao, Shiwen, Hu, Long, \& Leung, Victor C. M. (2014). CAP: Community Activity Prediction Based on Big Data Analysis. leee Network, 28(4), 52-57. http://dx.doi.org/10.1109/MNET.2014.6863132

\section{Authors}

Igor Perko is an assistant professor at the University of Maribor, Faculty of Economics and Business, Slovenia. His PhD thesis was "Intelligent agents in management information systems." His research interests include business intelligence systems and Big Data, focusing on cooperation support in business ecosystems. He is connecting the use of knowledge management structures, business data sharing, Big Data, cloud technologies, and predictive analytics to provide intelligence support of trans-business processes. He is the author of professional and scientific papers, actively involved in business ICT development, and a member of WOSC.

Peter Ototsky graduated as applied mathematics and physics master in 2005 in Moscow Institute of Physics and Technology (Moscow). From 2003 to 2005 he worked in information technologies domain supporting SAP R/3 in JSC Gasprom Export. In 2008 he received PhD for a complex systems modelling at synergetic science school in the Keldysh Institute of Applied Mathematics, Russian Academy of Science. Since 2009 works as a commercial director in a wholesale company. From 2010 to 2012 was teaching a course of systems modelling and management cybernetics. At 2010 co-found a Moscow Management Cybernetics club. Since 2008 he leads a Cognitive Centers team at the Keldysh Institute of Applied Mathematics performing 
research and several projects for regional administration and private companies. His research interests are modelling, cybernetics, complexity management and innovation management.

\section{Veliki podatki za soudeležence poslovnih ekosistemov}

\section{Izvleček}

V predstavljeni raziskavi povezujemo nekaj najbolj perspektivnih področij uporabe velikih podatkov z reprezentativnimi predstavniki skupin poslovnih ekosistemov. Z analizo literature identificiramo trenutno stanje razvoja velikih podatkov na pomembnejših področjih njihove uporabe: pri osebnem trženju, zdravstvenih storitvah, priložnostih za delo, finančnih storitvah in zagotavljanju varnosti. Teorije sistema smo uporabili za identifikacijo predstavnikov skupin, na katere vplivajo veliki podatki: posamezniki, mala in srednja podjetja, velike organizacije, ponudniki informacij in regulatorji. Razmerja med področji uporabe velikih podatkov in deležniki pojasnjujemo z analizo priložnosti in tveganj ter strategij, s katerimi se ti deležniki odzivajo. Za vizualizacijo relacij smo oblikovali model z orodji sistemske dinamike.

Ključne besede: poslovni ekosistemi, veliki podatki, ponudniki informacij, sistemska dinamika 